\title{
A Positive Outlook towards the Lesser Known: Wild Rose Brings Hope
}

\author{
${ }^{1}$ Soumen Maitra, ${ }^{2}$ Pratik Satya, ${ }^{3}$ L. C. De \\ ${ }^{1}$ Uttar BangaKrishi Viswavidyalaya, Pundibari, Cooch Behar, West Bengal, India \\ ${ }^{2}$ ICAR - Central Research Institute for Jute and Allied Fibres, Barrackpore, West Bengal, India \\ ${ }^{3}$ ICAR - National Research Centre for Orchids, Pakyong, Sikkim, India.
}

\begin{abstract}
The genus Rosa includes over 120 species prevalent in the temperate and subtropical zones of the Northern hemisphere.Among the wild species of rose - Rosa canina, Rosa multiflora, Rosa rugosa, Rosa glauca, Rosa laevigata, Rosa woodsii, Rosa chinensis, Rosa setigera, Rosa gigantea, Rosa gymnocarpa, Rosa serica, Rosa longicuspis, Rosa nutkana etc. are common. Wild Rose, contrary to common belief, has a number of unique uses starting from delicious recipes to treatment of several diseases. The hips are commonly used as food in many countries due to high nutritional qualities. Rose hips have very high medicinal value and are used in several herbal formulations to cure many ailments. The fruit extract has antioxidant, anti-inflammatory, antiulcerogenic and anti-mutagenic activities. It contains high amount of Vitamin C, carotenoids, flavonoids, phenolic compounds and other secondary metabolites.A unique approach for utilization of rose is to use rosewater spray as attractant for insects to aid pollination in cross pollinated plants. An important aspect of disease management is the utilization of resistant types (either a species or a variety) to a particular pathogen.
\end{abstract}

Keywords: Rosa, wild rose, hips.

\section{INTRODUCTION}

From time immemorial man has admired rose for its aesthetic beauty and unique fragrance. Rose has been a companion to mankind since the inception of civilization. Fossils of 30 million years old rose have been excavated in Colorado. In India, rose was mentioned in ancient Sanskrit verses. The genus Rosa includes over 120 species prevalent in the temperate and subtropical zones of the Northern hemisphere. The genus Rosa L. belongs to the plant family Rosaceae. According to the system of Rehder 1940, it is divided into four subgenera; Hulthemia, Platyrhodon, HesperrhodosandEurosa (Wissemann, 2003). The subgenus Eurosa, contains largest number of species.

Development of new cultivated rose types like Hybrid Tea, Floribunda, Polyantha etc. through rigorous market oriented selection and breeding efforts have generated several attractive flower form and colours leading to predominance of cultivated species while wild rose species have gone into oblivion. Conventionally cultivated roses are used for-

- Cut flower

- Loose flower in bouquets, buttonholes and in other floristry items

- Garden plant for landscaping

- Potted plant

- As ornamental hedge

- Preparation of perfumeries etc.

Among the wild species of rose - Rosa canina, Rosa multiflora, Rosa rugosa, Rosa glauca, Rosa laevigata, Rosa woodsii, Rosa chinensis, Rosa setigera, Rosa gigantea, Rosa gymnocarpa, Rosa serica, Rosa longicuspis, Rosa nutkana etc. are common examples (Table - 1). Wild rose species are generally neglected commercially due to their unattractive flower form and colour as rose is the highly demanding ornamental flower worldwide. Garden lovers dislike wild roses due to their lack of 


\section{Soumen Maitra et.al}

aesthetic beauty and spiny nature (Table 2). However, these species are utilized as food, herbal medicines and health protective covers in localized pockets since ancient times. Rose hipshave long been used as food for native people of Northern hemisphere. The fruit is a single seeded pseudocarp with fleshy walls. It contains high amount of vitamin C, Calcium, phosphorus and iron than oranges, making them as especially nutritious food (Pal, 1972). Besides food, rose hips have been traditionally used as herbal medicine from a long time. The Costanoans used a decoction of rose hips internally for rheumatism, indigestion, kidney ailments and fever and externally as a wash for scabs and sores. During World War - II, in England, Rose hip was used to offset the shortage of citrus fruit and prevent scurvy. In Turkey, Rose hips are used in tea sachet as a health drink. Hips are important component of all rose species and hence the study on the species-wise differences in quality parameter is essential. Some wild rose species are mentioned below -

Table 1. Some wild species of Rose

\begin{tabular}{|c|c|c|c|}
\hline Sl. No. & Common name & Botanical name & Synonymous to \\
\hline 1 & $\begin{array}{l}\text { Briar Rose, Dog Rose, White-flowered } \\
\text { Rose, Dog Briar, Hondsroos, Redoute } \\
\text { Rose }\end{array}$ & Rosa canina & $\begin{array}{l}\text { Rosa leucantha } \\
\text { Rosa pseudoscabrata } \\
\text { Rosa sphaerica } \\
\text { Rosa Surculosa }\end{array}$ \\
\hline 2 & Buschel Rose, Wreath Rose & Rosa multiflora & -- \\
\hline 3 & Boat-leaved Rose, Hemp-leaved Rose & Rosa cannobina & $\begin{array}{l}\text { Rosa alba cimbaefolia } \\
\text { Rosa alba cymbaefolia }\end{array}$ \\
\hline 4 & $\begin{array}{l}\text { Japanese Rose, Wrinkle-leaved Rose, } \\
\text { Saltspray Rose, Ramanus Rose }\end{array}$ & Rosa rugosa & -- \\
\hline 5 & $\begin{array}{l}\text { Large-flowered Climber, Redoute Rose, } \\
\text { Red-leaved Rose, Red Leaf Rose, Hecht- } \\
\text { Rose }\end{array}$ & Rosa glauca & $\begin{array}{l}\text { Rosa ferruginea } \\
\text { Rosa glaucarubrifolia } \\
\text { Rosa pyrenaica } \\
\text { Rosa romana } \\
\text { Rosa rubifolia } \\
\end{array}$ \\
\hline 6 & Cherookee Rose, Snow-white Rose & Rosa laevigata & Rosa nivea \\
\hline 7 & Woods Rose, Mountain Rose & Rosa woodsii & \\
\hline 8 & Wingthorn Rose, Wild Rose & $\begin{array}{l}\text { Rosa sericia var. } \\
\text { pteracantha }\end{array}$ & $\begin{array}{l}\text { Rosa omeiensis var. } \\
\text { pteracantha }\end{array}$ \\
\hline 9 & $\begin{array}{l}\text { Burr Rose, Chestnut Rose, Chinguapin } \\
\text { Rose }\end{array}$ & Rosa roxburghii & \\
\hline 10 & Prairie Rose & Rosa setigera & -- \\
\hline 11 & Virginia Rose & Rosa virginiana & -- \\
\hline 12 & Alba Rose & Rosa alba foliacea & -- \\
\hline 13 & Himalayan Musk Rose & Rosa brunonii & -- \\
\hline 14 & Memorial Rose & Rosa wichuraiana & -- \\
\hline 15 & Sweetbrier Rose & Rosa eglanteria & $\begin{array}{l}\text { Rosa eglanteria var. } \\
\text { punicea } \\
\text { Rosa rubiginosa }\end{array}$ \\
\hline 16 & Manchu Rose & Rosa xanthiana & Rosa hugonis \\
\hline 17 & Climbing Rose & Rosa filipes & -- \\
\hline 18 & Prickly Wild Rose & Rosa acicularis & -- \\
\hline 19 & Prairie Wild Rose & Rosa arkansana & -- \\
\hline 20 & Field Rose & Rosa arvensis & -- \\
\hline 21 & $\begin{array}{l}\text { Hudson Bay Rose, Labrador Rose, } \\
\text { Meadow Rose, Smooth Rose }\end{array}$ & Rosa blanda & - \\
\hline 22 & Cinnamon Rose & Rosa davurica & -- \\
\hline 23 & Father David's Rose & Rosa davidii & -- \\
\hline 24 & Leafy Rose, White Prairie Rose & Rosa foliolosa & -- \\
\hline 25 & Pine Scented Rose & Rosa glutinosa & -- \\
\hline 26 & $\begin{array}{l}\text { Little Woods Rose, Dwarf Rose, Bald Hip } \\
\text { Rose }\end{array}$ & Rosa gymnocarpa & -- \\
\hline 27 & Helen Wilson's Rose & Rosa helenae & - \\
\hline 28 & Wild Rose & Rosa horrida & Rosa biebersteinii \\
\hline 29 & Wild Rose & Rosa longicuspis & Rosa lucens \\
\hline 30 & Shining Rose, Glanz Rose & Rosa nitida & -- \\
\hline
\end{tabular}


A Positive Outlook Towards the Lesser Known: Wild Rose Brings Hope

\begin{tabular}{|l|l|l|l|}
\hline \hline Sl. No. & Common name & Botanical name & Synonymous to \\
\hline 31 & Nutka Rose & Rosa nutkana & Rosa nutkanaensis \\
\hline 32 & Alpine Hedge Rose & Rosa alpina & $\begin{array}{l}\text { Rosa alpina } \text { var. } \\
\text { pendulina } \\
\text { Rosa pendulina }\end{array}$ \\
\hline 33 & $\begin{array}{l}\text { Scotch Brier Rose, Burnet Rose, Wild Iris } \\
\text { rose }\end{array}$ & Rosa spinosissima & Rosa pimpinellifolia \\
\hline 34 & Cluster Rose, Peafruit Rose & Rosa pisocarpa & -- \\
\hline 35 & Apple Rose & Rosa vilosa & Rosa pomifera \\
\hline 36 & Webb's Rose & Rosa webbiana & -- \\
\hline 37 & Caroline Rose, Sand Rose, Pasture Rose & Rosa carolina & $\begin{array}{l}\text { Rosa humilis } \\
\text { Rosa parviflora }\end{array}$ \\
\hline 38 & Wild Rose & Rosa rugosarubra & -- \\
\hline 39 & Species Rose & Rosa forrestiana & -- \\
\hline
\end{tabular}

Source: $w w w$. davesgarden.com

Table 2. Major characteristics of some Wild Rose species

\begin{tabular}{|c|c|}
\hline Rosa canina & $\begin{array}{l}\text { Abushy shrub growing in open fields in Europe and USA. Plant height varies from } \\
3-12 \text { feet with numerous stems covered with sharp spines. The leaves are odd- } \\
\text { pinnate, usually consisting of 5-7 leaflets - opposite, ovate, acute and serrate. } \\
\text { Flower colour varies from red to faint red. Scarlet to orange-red fruit contains many } \\
\text { one-seeded achenes. }\end{array}$ \\
\hline Rosa rubiginosa & $\begin{array}{l}\text { A free growing wild rose producing clusters of bright pink flowers with yellow } \\
\text { stamens and white centers. Grows about } 8 \text { to } 10 \text { feet tall. It blooms only once per } \\
\text { season. The foliage is apple-scented and fruit is bright-red. }\end{array}$ \\
\hline Rosa arkansana & $\begin{array}{l}\text { It is a spiny shrub (about } 45-50 \mathrm{~cm} \text { tall). Flower is pink and five-petalled with } \\
\text { yellow stamen. Only rose blooms on soft, prickly new stems that that grow directly } \\
\text { from the roots, as well as from new lateral shoots on older, woody stems. }\end{array}$ \\
\hline Rosa rugosa & $\begin{array}{l}\text { A shrub with crinkly leaves and dense spiny upright form with } 1.8-2 \mathrm{~m} \text { height. } \\
\text { Produces numerous highly fragrant pink flowers and small tomato shaped hips (sea } \\
\text { tomatoes). }\end{array}$ \\
\hline Rosa rugosa var. alba & $\begin{array}{l}\text { Similar foliage character like } R \text {. rugosa. Flowers are white and fruits are deep } \\
\text { bright orange. Unique characters like cold hardiness, disease resistance and } \\
\text { flowering in multiple flushes are present. }\end{array}$ \\
\hline Rosa glauca & $\begin{array}{l}\text { Grown primarily for its foliage. The leaves are glaucous and coppery-violet. Plants } \\
\text { are } 2-3 \mathrm{~m} \text { tall. It has attractive deep cherry flowers and orange-red hips. }\end{array}$ \\
\hline Rosa gymnocarpa & $\begin{array}{l}\text { A shrub with height about } 1 \mathrm{~m} \text {, has alternate, pinnately compound leaves with 5-7 } \\
\text { ovate and serrated leaflets, produces small pink fragrant five-petalled flowers. } \\
\text { Bristles are present instead of thorn. }\end{array}$ \\
\hline Rosa nutkana & $\begin{array}{l}\text { Deciduous plant with fast growing green foliage, that are } 1-2 \mathrm{~m} \text { tall. Pink fragrant } \\
\text { flowers are edible. Large bright orange fruits are also fragrant. }\end{array}$ \\
\hline Rosa pisocarpa & $\begin{array}{l}\text { Produces large branches with vicious thorn. Leaflets are pointed sharply. Pink } \\
\text { flowers are borne in clusters. }\end{array}$ \\
\hline Rosa woodsii & $\begin{array}{l}\text { Drought tolerant hardy shrub that can grow on rocky mountain and are } 1-1.2 \mathrm{~m} \text { tall. } \\
\text { Flowers are pink and fruits are glossy red. }\end{array}$ \\
\hline Rosa acicularis & $\begin{array}{l}\text { Bushy shrub with dense bristles, } 30-120 \mathrm{~cm} \text { tall, leaves pinnate with } 5-7 \text { coarsely } \\
\text { serrated leaflets. Pink flowers are solitary. Fruits are pear shaped and orange to red. }\end{array}$ \\
\hline Rosa californica & $\begin{array}{l}\text { Deciduous upright shrub with green fragrant foliage. Thorns are hooked. Have pink } \\
\text { five-petalled scented flowers. }\end{array}$ \\
\hline
\end{tabular}

\section{UTILIZATION OF WILD ROSES}

Wild Rose, contrary to common belief, has a number of unique uses starting from delicious recipes to treatment of several diseases. The hips are commonly used as food in many countries due to high nutritional qualities. Petals are used in sandwiches, salads and omlettes for flavor and nice reddish colouration. Rose petals and hips are the bases to many jellies, preserves and honeys. Several recipes are available for preparation of jam, syrup, lemonade, jelly etc.

Rose hips have very high medicinal value and are used in several herbal formulations to cure many ailments. The fruit extract has antioxidant, anti-inflammatory, anti-ulcerogenic and anti-mutagenic activities. It contains high amount of Vitamin C, carotenoids, flavonoids, phenolic compounds and other secondary metabolites. Rose hips is used to treat infections of the bladder and kidney, diarrhea, 
skin problems, colds and flu, sore throat, fatigue, inflammation, stress and nervousness. Rose honey is known to help sooth sore throats and wet rose petals can be placed on cuts and sores. As the petals dry they will form a sort of natural bandage. Rosa canina are particularly beneficial for the digestive apparatus and produce a diuretic effectwithout irritating the kidneys. It helps in curing kidney stones. It eliminates uric acid accumulation and helps in rheumatism and gout.

Rose hips and petals are used to flavor tea. Rosa rugosa, Rosa canina, Rosa rubiginosa etc. are commonly reported for such use. There are many commercial tea products supplemented with rose hips. A number of skin care products like cleansing lotions, facial toner, moisture cream etc. from rose have been developed by many companies. Weleda wild rose skin care Inc. has developed many products using Rosa moschata as a base material. Wild roses are sedative, antiseptic, vulnary, nervine and digestive, whereas, especially Dog rose is having medicinal properties like - astringent, carminative, diuretic, tonic etc. Multifarious uses of different parts (mainly rose hips and flowers) of wild roses unveil several compounds like - Citric acid, flavonoids, fructose, malic acid, sucrose, tannins, vitamins $\mathrm{A}, \mathrm{B}_{3}, \mathrm{C}, \mathrm{D}, \mathrm{E}$, and $\mathrm{P}$, Phenyl ethyl alcohol, nerol, rhodinol, eugenol, calcium, phosphorus, iron, zinc etc.

Wild Rose is a very good protective hedge. The high thorny types like Rosa rugosa, Rosa rugosa var. alba and Rosa californica can be used for developing protective fencing at a very low cost.

Wild roses possess many important characters those may be transferred to the cultivated types through hybridization and selection. For example Rosa woodsii is drought tolerant, Rosa rugosa var. alba has cold hardiness, disease resistance and flowering in multiple flushes, Rosa arkansana has short stature and Rosa gymnocarpa has soft bristles instead of thorns. These characters, if incorporated in cultivated types, would be very helpful in future Rose breeding programme. Wild species are also resistant to many diseases. Rosa acicularis var. nipponensis, Rosa polyantha and Rosa rugosa cv. Pink expressed high resistance against black spot (Diplocarpon rosae Wolf.) (Boontiang and Yamaguchi, 2002). Carlson (2000) transferred resistance to black spot to cultivated types from wildRosa kordesii, Rosa elliptica and Rosa caninavar. blondeana has large fruit size and high ascorbic acid and mineral content.

Several fatty acids like oleic, palmitic, stearic, linoleic and linolenic acid was identified from Rosa rubiginosa and Rosa pendulina that has important use in cosmetic industry (Malteret, al., 2002). Concentrations of bisaborosaol A and carota-1,4-dienaldehyde as representative sesquiterpenes of Rosa rugosawere found to be positively correlated with the density of the glandular trichomes present in plants.

A unique approach for utilization of rose is to use rose-water spray as attractant for insects to aid pollination in cross pollinated plants. Al-Sahaf (2002) studied effect of rose water containing terpene alcohol on pollination of onion and found insects spent more time foraging on the rose water-sprayed plants than on the control plants, thereby increasing umbel diameter and seed setting.

Diseases like powdery mildew, downy mildew, rose rosette, black spot and die-back are having worldwide reputation as deadly for roses. An important aspect of disease management is the utilization of resistant types (either a species or a variety) to a particular pathogen. Schulz et al. (2009) reported that Rosa majalis is highly resistant to Podosphaera pannosa(causing powdery mildew disease), Peronospora sparsa (causing downy mildew disease) and Diplocarpon rosae (causing black spot disease). Resistance of wild rose species $R$. pendulina against downy mildew of Rose was also reported by Schulz and Debener (2010). Resistance against rose rosette disease had been reported in wild rose species like $R$. setigera, $R$. aricularis, $R$. arkansana, $R$. blanda, $R$. palustris, $R$. carolinaand $R$. spinosissima. Rosa roxburghii exhibited significantly higher level of resistance to powdery mildew disease of rose (Wen et al., 2006).

\section{REFERENCES}

[1] Al-Sahaf, F. H. (2002). Effect of planting method and rose water spray on seed production in onion (Allium cepa L.).Emirates Journal of Agricultural Sciences.14:14-23.

[2] Boontiang, K. and Yamaguchi, S. (2002). Breeding for resistance to the black spot (Diplocarponrosae Wolf.) disease in rose 2: a search for highly resistant rose species in Southern Japan.SABRAO Journal of Breeding and Genetics.34: 115-119. 
[3] Carlson, N. B. U. (2000). Resistance to Marssoninarosae in Rosa L. seedlings obtained from controlled crosses including germplasm L 83. ActaAgriculturaeScandinavica.Section B, Soil and Plant Sciences. 50: 176-182.

[4] Malter, D., Morsel, J. T. and Ebert, G. (2002). Composition of seed oils from wild growing fruit species. Erwerbsobstbau.44: 82-85.

[5] Pal, B. P. (1972).The Rose in India. ICAR, New Delhi.

[6] Schulz, D. F. and Debener, T. (2010). Downy mildew in roses: strategies for control. ActaHorticulturae (International Symposium on Rose Research and Cultivation).870: 21

[7] Schulz, D. F., Linde, M., Blechert, O. and Debener, T. (2009).Evaluation of genus Rosagermplasm for resistance to black spot, downy mildew and powdery mildew.European Journal of Horticultural Science.74: 1-9.

[8] Sipos, B. Z., Szabo, N., Steger, M. M. and Schmidt, G. (2002). Examination of valuable ingredients of some wild fruits.International Journal of Horticultural Sciences.8: 71-74.

[9] Wen, X., Xu, Q., Cao, Q. and Deng, X. (2006).Promising genetic resources for resistance to powdery mildew in chestnut rose (Rosa roxburghii) and its relatives in China.New Zealand Journal of Crop and Horticultural Science.34:183-188.

[10] Wissemann, V. (2003).Conventional taxonomy (wild roses). In: Roberts, A., Debener, T. and Gudin, S. (eds.). Encyclopedia of Rose Science. Elsevier, Oxford. pp-111-117. 


\section{AUTHORS' BIOGRAPHY}

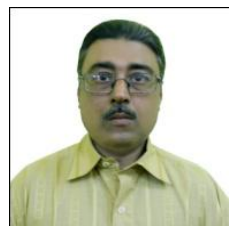

Dr. Soumen Maitra, presently Associate Professor, Department of Floriculture, Medicinal and Aromatic Plants, Faculty of Horticulture, Uttar Banga Krishi Viswavidyalaya, Pundibari, Coochbehar, West Bengal, India, was born on 29.09.1971 at Nabadwip, West Bengal, India. He has joined UBKV in the capacity of Assistant Professor on 10.12.2001. He has visited International Agricultural Research and Training Center (UTAEM), Izmir, Republic of Turkey in 2014, Cornell University, Ithaca, New York, USA in 2013, Huajhong Agricultural University, Hubei, P. R. of China in 2012 and Chinese Academy of Agricultural Sciences, Beijing, P. R. of China in 2010 under various academic and training programmes. He is the recipient of 7 awards offered by different organizations and institutions. He is associated to about 15 different courses in the University each year and acted as external examiner for about 51 times in different Universities of India. Dr. Maitra is associated to 9 different projects funded by external agencies in different capacities and registration of two different germplasm of medicinal plants by PGRC. He has published 40 research papers, 25 popular articles, 51 abstracts, 7 research articles, 2 books, 1 practical manual, 9 book chapters and 8 Bengali leaflets to his credit. He has organised 15 farmers' training programmes, delivered lectures for 141 times in different farmers' training programmes, delivered invited lectures for 22 times, acted as SMS in programmes in Mass media for 16 times and judge in fruit, flower and vegetable shows for 19 times.

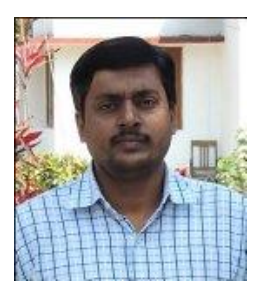

Pratik Satya is senior scientist (Plant Breeding) from ICAR-Central Research Institute for Jute and Allied Fibres, Barrackpore, Kolkata India. He earlier served in Uttar BangaKrishiViswavidyalaya, a state agricultural university of West Bengal, India as Assistant Professor and Head of the Department of Genetics and Plant Breeding. Dr. Satya has published more than 40 research papers in International and National journals with an h-index of 7 . He has also written more than 30 book chapters and reviews and has four books to his credit. His research interests are in the fields of genomics, population genetics andmolecular breeding.Apart from research, his passion is teaching.

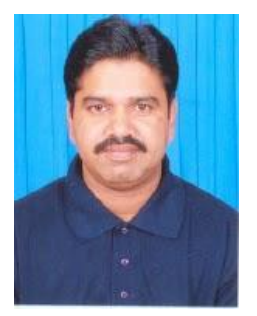

Dr. Lakshman Chandra De was born on $30^{\text {th }}$ March, 1967 in West Bengal. He graduated in B.Sc.(Ag) Hons. from BCKVV, West Bengal and obtained his both M.Sc and Ph. D. Degree in Horticulture-Floriculture from IARI, Pusa, New Delhi. Presently, he is a Principal Scientist working at ICAR-NRC for Orchids, Pakyong, Sikkim. He has 21 years research and extension experiences in production and postharvest technologies of horticultural crops of NEH Region and 4 years experience as Joint Director at ICAR, A.P.Centre. He has handled Nationally Funded Projects like NATP on 'IPNS for Vegetable Production System', Technology Mission on 'HMNEH', Mega Seed Project on flower crops and DUS Project on orchids. He has significant contribution in preparation of DUS Test Guidelines on Cymbidium, Dendrobium, Vanda, Cattleya, Phalaenopsis, Oncidium and Paphiopedilum orchids. He has published 100 research papers and written 25 book chapters, 24 Technical bulletins, 78 abstracts, 36 popular articles, 29 reports and 9 training manuals. He is the author of 14 popular books titled 'Advanced Commercial Floriculture', 'Medicinal Herbs and Flowers', 'Post-harvest Technology of Flowers and Ornamental Plants', 'Handbook of Edible Fruits', 'Handbook of Vegetable Crops', 'Ornamental Crop Breeding', 'Value Addition in Flowers and Orchids', Handbook of Gardening, 'Nursery and Landscaping' and 'Production Technology of Commercial Flowers', 'Production of Seed and Planting Material of Horticultural Crops', 'Commercial Orchids', 'Year Round Production of Orchids' and 'Protected Cultivation of Ornamental Plants' which have been well accepted as reference books in ICAR institutes, SAU's in India and abroad. He is awarded HSI Gold Medal in Floriculture in 2011, HSI Fellowship in 2013, IASR Fellowship in Horticulture (USA) in 2015, Heinrich Hertz Research Award in Horticulture (USA) in 2015, Antonie van Leewenhoek Research Award in Floriculture (USA) in 2016, IASR Fellowship in Floriculture (USA) in 2016 and CHAI Fellowship in 2016. He has been included in Biography of Asia/Pacific Who's Who (Vol. XIV) in 2016. He is a member of several scientific societies and National Level Committees and a reviewer of Journal of Botanical Sciences, Journal of Agriculture and Technology, British Biotechnology Journal, Journal of Biological Diversity, Indonesia and Journal of Agriculture and Crop Research and Associate Editor of The Himalayan Review. 